\title{
An Approach to Values Education in Africa (Annang) Perspective
}

\author{
Ukanga, Lambert Peter \\ Department of Philosophy, University of Nigeria, Nsukka \\ Eseohe Glory Okoedion \\ Department of Foreign Languages and Literary Studies, Universities of Nigeria, Nsukka
}

\begin{abstract}
The work looked at those values in Africa (Annang) educational system that can aid a sustaining Africa Traditional (Annang) society. For the Annang, humanity is manifested by the way one acts on, react to, and is acted upon by forces that inhabit the Annang Universe. Any act, therefore, which disrupt the people's harmonious existence in physical, social, political and religious dimensions are seen as idiok mkpo or vices. Using historical, textual and evaluative approach, we shall be concern with traditional Annang moral and social values and how these are imparted to those committed to traditional education in human values. What the Annang choose to teach, how they teach them and whom they teach raise questions on the philosophy of values education in traditional African (Annang) society.
\end{abstract}

Keywords: Values, Education, Annang, Traditional African Society.

DOI: $10.7176 / \mathrm{JAAS} / 57-02$

Publication date: August $31^{\text {st }} 2019$

\section{Introduction}

The Annang is an ethnic group in Nigeria, West Africa. With a population of over four million people, they are found mainly in southern part of Nigeria- The Annangs are indigenous to: "Abak, Ikot Ekpene, Ika, Ukana-fun, Etim- Ekpo, Obot Akara, Essien Udim and Oruk-Anam L.G.A. of Akwa Ibom state".

For the Annang, humanity is manifested by the way one acts on, reacts to, and is acted upon by forces that inhabit the Annang universe. Any act, therefore, which disrupt the people's harmonious existence in physical, social, political and religious dimensions are seen as idiok mkpo or vices. In this paper, I shall concern myself with traditional Annang moral and social values and how these are admonished to those committed to traditional education in human values.

\section{A Brief Account of African Annang Metaphysics}

The name Annang implies both language and ethnic group (people). The cosmos, in Annang thought is a world of forces: all beings are forces-some visible and some invisible; some tangible and some intangible. As forces they are active and dynamic; they impact and influence one another for good or for ill. Things exist in relation and there are no lone beings. In everything in Annang there is every other thing. Reality is therefore, a logical whole. ${ }^{2}$ This brings to bare the reason, why the individual forces in Annang are meaningful according to their relation to the whole, the traditional Annang community.

As Egbeke Aja would put it; to appreciate what count as value and values and their educational processes is in terms of the whole, not bit. ${ }^{3}$ Individuals in traditional African (Annang) are only a few part of reality; and to get to the reality, that is the whole, the Annang view human actions in relation to their effects on the whole. The real consists of the total system of relationship among the existing forces recognized by the Annang as values. That is to say, the customs and traditions of the Annang generate the value and vakues education among the Annang. The Annang recognized, among others, social values which include: marriage and family life, fellow feeling, solidarity and selflessness in children and adult.

\section{Values Education among the Traditional African Annang of Nigeria}

By ontology values are seemingly innate in human and activated by environmental spheres be it by education, religion, and societal norms etc. As Robb, W.M. rightly observes, values education is:

An activity which can take place in any organization during which people are assisted by others, who may be older, in authority or more experienced, to make explicit those values underlying their own behavior, to assess the effectiveness of these values and associated behaviourr, to assess the effectiveness of these values and associated for their own and others' long term well-being and to reflect on and acquire other values and behaviour which they themselves realize are more effective for long term wellbeing of self and others. ${ }^{4}$

The activity involved in values education can be formal or informal: It could be in the form of initiation ceremonies or in the form of organized games of a cultural group. And to test for effectiveness of the society 
and associated behaviour of the individual's and others .these attained through assigning various responsibilities to individuals and groups aimed at making explicit the values of traditional Igbo society. The requisite qualification of the facilitators varies according to the specific values to be made explicit. These are eloquently exemplified by traditional Annang in their values education.

\section{Marriage and Family Life}

According to Mbiti, marriage in traditional Africa is the focus of existence. It is the point where all members of a given community meet: the departed, the living, and those yet to be born." All the dimensions of time meet here...marriage is a drama in which everyone becomes an actor, or actress and not just a spectator.

Even though several attempts have been made to modernize the marriage institution in Annang nation, the marriage institution remains one of the oldest forms of social contract between a man and a woman, families, kindred, the living and the dead. One of the vital seed emanated from marriage that remains sacred in Annang land is (Ayeyen) Grandchild. "Ayeyen (grandchild) is one of the most important sacred institutions that were associated with dispute resolution in Annang for the simple reason that it has to do with life and dead." Ayeyen ( grandchild) are so respected that they can take anything that they wish in their grandparent home especially fruits of all kinds; and any conspiracy to stop the grandchild from doing so, lead to calamity or dead of any kind. Hence any dispute that rose between them will attract serious rituals for reconciliation. ${ }^{7}$

Various signs were attributed to infidelity on the part of married women; a certain spirit was and (is) believed to have been at work in such cases. This spirit is known as (ekpo nka agwo), ${ }^{8}$ spirit against adultery, and the testing properties were invoked by suspicious husbands publicly on the weekly palm wine day, (usen ukot). ${ }^{9}$ with these grave consequences, the public invocation of (ekpo nka agwo) provided an opportunity for confession and even reconciliation.

For the Annang, therefore, marriage and family life is a requirement from the corporate group- because it is the process through which a new link among members of the community is set in motion. It is a complex affair with economic, social and religious and philosophical dimensions. A person who has no descendent, according to the Annang, quenches the fire of life: his line of physical existence is blocked if he/she does not get married and bear children. So marriage and procreation in Annang thought are unit; without procreation marriage is incomplete.

Biologically, both husband and wife are reproduced in their children, thus perpetuating the chain of humanity; metaphysically, through their living heirs, the dead continue their existence. The Annang, believes, and they are convinced, that the living-dead are reincarnated, in part, so that aspects of their descendants, contends the Annang, quenches the fire of life: his line of physical existence is blocked if he or she does not get married and bear children. With this understanding, to get married is a sacred obligation which must neither be abused nor despised. Everybody has to get married and bear children. This is the greatest expectation of the individual. It is, therefore, irresponsible for one to be an unmarried adult. Make for the survival of the group. Marriage education starts in the family. When a child is born, it learns to be a social member of the community. In the home he or she plays being a father or a mother. As the children play, adults oversee what role each is playing by correcting either the boy or the girl for not really playing the role of a father or mother. At puberty the child goes through series of initiation. These initiations serve as the "birth" of the young people into the states of maturity and responsibility. At the family level, the girl-child is taught how to cook: She stays by her mother, prepares the ingredients for food with the mother and learns the stages of preparing different dishes. When she is deemed to have learned enough, she is allowed to prepare alone the family meals. The mother teaches her how to clean the young ones, present food to their family and visitors. She is taught how to receive visitors cordially without exposing herself to temptation.

Puberty rites in Annang are dramatized and effect the incorporation of the young girls into the full life of their community. On reporting her first menstruation to the parents, the girl's family performs the puberty ceremony for her. With her age mates, she is confined in the house. She rubs her body with local cream made up of fresh palm oil mixed with Idiuood -red-wood pulp which is ground into powder. On an appointed date, the girl "comes out" robust and fresh. Experienced women in the compound teach her how to take care of herself during menstruation periods. She is taught to avoid men the dos and don'ts of matured female members of the community are listed down for her internalization. The feast serves as a venue to alert the community that the girl is matured and ready for family life. All members of the community are there and then guards over her morality.

Male children enjoy different types of puberty rites. On reporting of his first experience of his bed- wetting, the tradition Annang advisees his son that his now a grown-up and should not play carelessly with the opposite sex. The young adults are encouraged to mix freely with people of their age grade and of the same sex for such Endeavour's as fishing, cutting of palm fruits and hurting expeditions. By trial and error, the boy learns the art of fishing, and cutting of palm fruits.The first bird to be shot by a male-child is celebrated. With the mates, the "achiever", the boy, dances round the compound to celebrate the feast of being able to aim and shoot down a 
bird. He and others learns to, not only works together, but also to celebrate the success of others. Those who have not yet shoot birds are thereby encouraged to do so. Thus, they learn that the success of their peer, is by extension, theirs.

Apart from their social significance, initiation rites among the Annang have educational purpose. One of such purpose is to introduce young people to matter of sex, marriage, procreation and family life. Since the whole community participates in the initiation rites, it is therein the entire corporate body of society prepares the young people, albeit, informally for marriage and family life in the traditional Annang set up. Girls are taught how to cook, how to behave towards men, how to care for children, and how to look after a man. They see their mother do them and they copy. The boys are taught what most concern men, for example like looking after the family livestock, acquiring wealth which one would give to one's would-be in-laws and how to be responsible heads of families. These, the parents do by exposing their sons to the professions of the family: they learn by doing what their fathers do.

\section{Solidarity/Fellow Feelings and Community Obedience}

In the traditional Annang community, experienced elderly wives compound serves as a maternity for child delivery. Elderly women who have been taught the skill of midwifery took the role of child delivery. In Annang tradition, they in other hand introduce a baby into the family and to the whole community with cheerfulness and with prayers. Gbadegesin writing on the Yoruba contemporary realities attests the: "Co- wives are on hand to tease the growing child, chanting the family praise names and demanding gratification in return" ${ }^{10}$ All these, with time, raise the consciousness of the child not only as a member of a family but as an integral part of a community. The child thus begins to internalize the norms and values of the community. In this kind of environment, growing children are made to see themselves as a part of a household and not as atoms. ${ }^{11}$ They learn to appreciate their intrinsic relationship to others, and learn to internalized the interdependent existence of their lives with others. Thus the foundation for the spirit of solidarity and fellow feelings is laid.

At the community level, the young are exposed to the display of selfless service and obedience by members of the community through festival chant, folktales, songs, and proverbs. The listeners of the story are challenged to reflect on the story. Such didactic stories are often ended with: He, who has ears, let him hear" 12 (ake aniede utong ndikop yak akop). Thus, the young learn to see themselves as those who should carry the banner of the values of the community. Every member grows to learn, informal, to consider himself or herself as an integral part of the whole; each is made to appreciate role towards the good of all.

On this note, K. A. Busia, states this succinctly when he commented about the Akans of Ghana that: "The individual is brought up to think of himself in relation to his group and to behave always in such a way as to bring honour and not disgrace to its member; the ideal set before is that of mutual helpfulness and cooperation within the group of Kinsfolk". ${ }^{13}$ This view is corroborated by Kwame Gyekye when he cites an Akan proverb: "The prosperity (or well being) of man depends upon his fellow man." 14 Later in life, parents begin to introduce their sons and daughters to the traditional rituals at the ancestral shrines in the compound. The father who takes his son to farm, introduces him to farming. The same can be said of other professions. The Annang adult follows the footsteps of his/her father/mother. Thus seen, values education among the Annang is carried out mainly by elders (including parents), and people in Authority. In addition, special agencies for the inculcation of certain societal values into young adults are resorted to. Secret societies are in this category. Through initiations, adults are taught various values; they turn the adults into morally responsible individuals.

\section{Issues on the African (Annang) Values Education}

Schofield maintains that for a process to be education, it has to satisfy the following conditions:

1. It must imply the transmission of what is worthwhile to those who become committed to it ;

2. It must involve knowledge and understanding and some sort of "cognitive perspective" which is not inert; and

3. It, at least, rules out some producers of transmission (for example, indoctrination) on the ground that they lack wittingness and voluntariness on the part of the learner.

From our account, values education in traditional Africa (Annang) setting in terms of contents, attitudes, and methods does the process qualify as education? The task of education is, broadly speaking, to develop people in such a way that will be enabled to take pleasure in life while contributing to the maximization of pleasure in the community as a whole. What is educationally worthwhile in a given human society is therefore, whatever will contribute to that end. The content of traditional Annang values education are aimed at inculcating values and attributes that will enable people committed to it to take pleasure in life. And since people are not borne with pre-ordained to take pleasure only in a certain restricted range of activities, education in human value see it as its task to expose the young and the adults to those values through various activities that the societies deems most likely to contribute to the well being of the self and the community.

Hence, the Annang education in values is rituals. ${ }^{15}$ Although the immediate pleasure of the subject is 
discounted, the ultimate aim of the education is to bring up people in such a way that they find their pleasure and well being in the educational activities. Judging by the methods, it might be doubted by some people with the Western frame of mind whether the methods of education in human values do not amount to indoctrination. My answer is "No". After listening to the stories, the subject the subject raised question such as: What happened to the last child? Why did the tortoise do that? So, there is some element of dialogue; the values are not just handed down for the children to learn and put into practice. That is, it is not "basically the straight forward transmission of information regarding what is wrong and what is right." More so, the people committed to it, on their own, pursue the activities of their choice (by joining, say, the secret society or profession they like) voluntarily. The society only directs the interest and attention of the subject to those activities that would most effectively bring about the desired changes in the behaviour of those committed to the educational activities. Incidentally, the activities are educationally worthwhile for imparting the societal values.

Furthermore, it is important to note that for a process to be called indoctrination, the aim and the intention of the person or persons carrying out the process must be determined, and not the content and the method of the process. Indoctrination, deliberately, suppresses both reason and evidence to achieve its aim which is the inculcation of beliefs. It aims at denying insight; hence, it resorts to methods which are reprehensive and morally objectionable to all save the indoctrinators themselves. So, indoctrination is never undertaken with the well being of the indoctrinated in mind. Against this back ground knowledge of what indoctrination stands for, I argue that the values among the Annang is NOT indoctrination. Rather, than suppressing initiative, it enables those committed to it to explore their environment for a better understanding of it. This is essence of the various initiation rites. Whereas indoctrination aims to close the mind because it puts forward doctrines and dogmas and set of beliefs so authoritatively that they appear beyond the reach of normal investigation, traditional Annang values education in human values aims to open and develop the mind. Beliefs and doctrines are put forward in such a way as to make those committed to them critical. The series of initiation rites rather than denying insight enable individual to acquire cognitive perspectives.

They acquire the ability to see all the aspect of the situation which are denied the uninitiated. So the process is never undertaken to the detriment of the individuals committed to it. Experience reveals that the well being of the people is its ultimate aim. Through initiation rites people are ritually introduced to the art of communal living. They are introduced to the values of the extended family system. Initiations mark the beginning of acquiring knowledge otherwise not accessible to the individual. Through initiation, the individual acquire the virtues of endurance, obedience, and knowledge of the mysteries of man and womanhood relationships.

Traditional education in Annang land saw the great training of girls to womanhood; "especially in Mbokpo traditional institutes; marriage was an exclusive arrangement of parent after careful scrutiny of the would-be husband." 16 But much of values education is through the church and the schools. Consequently, parents no longer see it as their responsibilities to educate their young on the values of the society. Thus, most traditional Annang value absolutes are being systematically dethroned. On the part of the Igbos, Egbeke Aja would say: "the fabrics of traditional African values are being shaken to the roots. Hence the social and moral dilemma in which the contemporary Igbo finds him or herself." 17

More so, in the current erra, the Government and private sector in Annag Land (Akwa Ibom State) at large, saw and knew the need to place high premium on quality education for the future generation of Annang children. This is done with a full sense of retaining the philosophy of education in its traditional wealth, to nurture a school system in Annang land to produce elite who can think for the posterity.

In conclusion, some scholars would debate that values are not facts, for the Annang values are facts: they are both moral and social absolutes. The community identifies them for their members. The traditional Annang stress on the whole and the inter-relation of all its parts, is a fruitful point of departure for understanding education in human values in Annang cultural milieu in terms of its contents, method and aims.

Thus Annang traditional modes of education are informal, practical, utilitarian, and indeed pragmatic. Oral literature, personal examples and activities are the means of imparting humans values. In the face growing modernization and western education, in dethroning our Annang value absolutes, we must take care not to exile our ontological imperatives; fro after all they had worked for us and do work for us. We live by them both consciously and unconsciously. I end it here by the words of Egbeke Aja: "Man does not, cannot, live in a valueless world." 18

\section{References}

${ }^{1}$ Daniel Ekanem, Annang National Consciousness, Ikot Ekpene: Ritman University Press, 2016), 45

${ }^{2}$ Egbeke Aja, Doing African Philosophy, (Nsukka: University of Nigeria Press Ltd, 2015), 278

${ }^{3}$ Egbeke Aja, Doing African Philosophy, (Nsukka: University of Nigeria Press Ltd, 2015), 278

${ }^{5}$ John S. Mbiti, African Religion and Philosophy, (London: Heinemann, 1969), 133

${ }^{6}$ Daniel Ekanem, Annang National Consciousness, Ikot Ekpene: Ritman University Press, 2016), 80

${ }^{7}$ Daniel Ekanem, Annang National Consciousness, Ikot Ekpene: Ritman University Press, 2016), 81 
${ }^{8}$ Daniel Ekanem, Annang National Consciousness, Ikot Ekpene: Ritman University Press, 2016), 82

${ }^{9}$ Daniel Ekanem, Annang National Consciousness, Ikot Ekpene: Ritman University Press, 2016), 82

${ }^{10}$ Segun Gbadegesin, African Philosophy: Traditional Yoruba Philosophy and Contemporary Realities,(New York: Peter Lang, 1991), 62

${ }^{11}$ Segun Gbadegesin, African Philosophy: Traditional Yoruba Philosophy and Contemporary Realities, 63 ${ }^{12}$ Egbeke Aja, Doing African Philosophy, (Nsukka: University of Nigeria Press Ltd, 2015), 282

${ }^{13}$ K. A. Busia, The Challenge of Africa, (New York: Praeger press, 1962), 33

${ }^{14}$ Kwame Gyekye, An Essay on African Philosophical Thought: The Akan Conceptual Scheme, (Philadelphia, Temple,University Press,1995),155

${ }^{15} \mathrm{John}$ S. Mbiti, African Religion and Philosophy, 133

${ }^{16}$ Patty Ineme and Joseph Udondata, A Compendium of Annang Culture, (Ikot Ekpene: Ritman Press, 2014), 67

${ }^{17}$ Aja, Egbeke. Doing African Philosophy. Nsukka: (University of Nigeria Press Ltd, 2015), 286

${ }^{18}$ Egbeke Aja, Doing African Philosophy,(Nsukka: University of Nigeria Press Ltd,2015), 278 